DOI: 10.17707/AgricultForest.61.4.09

\author{
Konstantin KORLYAKOV*, \\ Antonina KOSOLAPOVA, Venera YAMALTDINOVA ${ }^{1}$
}

\title{
IMPACT OF FERTILIZATION ON CROP YIELDS AND SOIL STATUS WITH EMPHASIS ON HEAVY METALS
}

\section{SUMMARY}

Long-term study of organic, mineral and complex fertilization systems was fulfilled on experimental plots of Perm Agricultural Research Institute in 19932010 years. Stationary experiment was founded in 1969. Average yields in fourth and fifth rotations varied from 2650 to $3859 \mathrm{FU}^{-1}$ as influenced by fertilization systems. All studied systems provided yields raising compared with control treatment (no fertilizers). The highest grain yield supplements were obtained for spring wheat (from 0.47 to $1.55 \mathrm{t} \mathrm{ha}^{-1}$ ) and oat (from 0.54 to $1.02 \mathrm{t} \mathrm{ha}^{-1}$ ). Essential advantage of complex fertilization systems was determined. Using these systems guaranteed raising of all soil fertility basic parameters, including humus, mobile phosphorus and potassium content, soil microbiological activity, and positive basic nutrition elements balances. The maximum grain yields (up to $3.85 \mathrm{t} \mathrm{ha}^{-1}$ for spring wheat) but minimum crop returns were obtained from combination of manure total rate $160 \mathrm{t} \mathrm{ha}^{-1}$ within rotation and equivalent mineral fertilizers application (fertilizers rates are defined according the nutrients quantity in manure). The highest net returns were gained after mineral fertilizers application. Mineral fertilizers and farmyard manure (FYM) may be the sources of heavy metals contamination. The essential pollution by heavy metals in agricultural product and soil was not noted in given studies after long-term (about forty years) manure and mineral fertilization.

Key words: fertilization system, farmyard manure, crop rotation productivity, nutrient balance, heavy metals content

\section{INTRODUCTION}

One of the main problems of modern husbandry is the preservation and increasing of soil fertility, as well-being base of any country and the whole of mankind on our planet (Mineev, 2008). Dominant part of arable lands in Perm Region (69 \%) set on sod-podsolic soils (Umbric Albeluvisols Abruptic) defining by poor natural fertility. Systematic and complex fertilization of these soils proved to be the compulsory condition of any crop high yields (Petuchov, et al., 1964; Naydin, et al, 1967). Even on the cultivated sod-podsolic soils considerable

\footnotetext{
${ }^{1}$ Konstantin Korlyakov* (corresponding author: korlyakovkn@rambler.ru), Antonina Kosolapova, Venera Yamaltdinova, Perm Agricultural Research Institute, 614532, Lobanovo, Perm region, RUSSIA

Paper presented at the $6^{\text {th }}$ International Scientific Agricultural Symposium "AGROSYM 2015"

Note: The authors declare that they have no conflicts of interest. Authorship Form signed online.
} 
decline of grain yields and phosphorus and potassium available forms in soil were observed without fertilizers application (Voytovich, et al., 1990).Long application of fertilizers together with their positive impact on agricultural crops productivity and soil fertility has also negative influence on the agricultural biocenoses, caused by heavy metals accumulation in soils and vegetative production (Ramad, 1981; Alexeev, 1987;Obuchov et al, 1992; Ladonin, 1997; Mineev, et al., 1999). However, such fears are not always justified. Results of long-term field experiments in Leningrad Research Institute (Nebolsin, et al., 2005; Yakovleva, 2009) show that farming impact in soils pollution by heavy metals is insignificant (1 - $2 \%)$.

The objective of given experimental work is to compare the influence of long-term application of various fertilizers systems on arable crops yields, fertility of sod-podsolic heavy loam soil, and heavy metals content in grain and soil.

\section{MATERIAL AND METHODS}

Experimental work was fulfilled in 1993-2010 in long-term stationary field experiment on the experimental farm of Perm Agricultural Research Institute. The experimental plots located on sod shallow-podsolic heavy loam soil with humus content $2.1-2.2 \%$, pH $5.4-5.5, \mathrm{P}_{2} \mathrm{O}_{5}$ content 125 and $\mathrm{K}_{2} \mathrm{O}-170$ mg kg-1. (1969, before experiment foundation).

Table 1: Sheme of farmyard manure (FYM) and NPK-fertilizer application in the long-term stationary field experiment (1969 - 2009: five eight-course crop rotations)

\begin{tabular}{|c|c|c|c|c|c|c|}
\hline & \multirow[b]{2}{*}{ Treatment } & \multicolumn{5}{|c|}{$\begin{array}{c}\text { Sequence of crop rotations (CR) from } 1969 \text { to } 2009 \text { (two } \\
\text { replications in time.) }\end{array}$} \\
\hline & & \begin{tabular}{|c} 
CR-1 1969- \\
1976 1970- \\
1977
\end{tabular} & $\begin{array}{c}\text { CR-2 1977- } \\
19841978- \\
1985\end{array}$ & $\begin{array}{c}\text { CR-3 1985- } \\
1992 \text { 1986- } \\
1993\end{array}$ & $\begin{array}{c}\text { CR-4 1993- } \\
2000 \text { 1994- } \\
2001\end{array}$ & $\begin{array}{c}\text { CR-5 2001- } \\
2008 \text { 2002- } \\
2009\end{array}$ \\
\hline $\boldsymbol{a}$ & Control & \multirow{3}{*}{\multicolumn{5}{|c|}{$\begin{array}{l}\text { No fertilized in the } 1969-2009 \text { period } \\
\text { FYM was applied two times ( } 2 \text { x } 50 \% \text { of planned rate during } \\
\text { each crop rotation: for winter rye and potato: } 20,40,80 \mathrm{tha}^{-1} \\
\text { before plowing); }\end{array}$}} \\
\hline $\boldsymbol{b}$ & FYM-80 tha ${ }^{-1}$ & & & & & \\
\hline$c$ & FYM-160 t ha ${ }^{-1}$ & & & & & \\
\hline$d$ & NPK- eq 80 & \multirow{2}{*}{\multicolumn{5}{|c|}{$\begin{array}{l}\text { NPK-fertilizer (added in equivalent amount of nutrients } \\
\text { contains in FYM) Rates were distributed between winter rye, } \\
\text { wheat, barley, potato and oats. Meadow clover was not } \\
\text { fertilized }\end{array}$}} \\
\hline $\boldsymbol{e}$ & NPK-eq 160 & & & & & \\
\hline$f$ & $\begin{array}{l}\text { FYM-40 + NPK-eq } \\
40\end{array}$ & \multirow{3}{*}{\multicolumn{5}{|c|}{$\begin{array}{l}\text { Complex fertilization systems (FYM with equivalent rates of } \\
\text { mineral fertilizers). }\end{array}$}} \\
\hline $\boldsymbol{g}$ & $\begin{array}{l}\text { FYM-80 + NPK-eq } \\
80\end{array}$ & & & & & \\
\hline & $\begin{array}{l}\text { FYM-160 + NPK- } \\
\text { eq } 160\end{array}$ & & & & & \\
\hline
\end{tabular}


Field trials were executed in fallow grain grass rotation with following rotation scheme: bare fallow, winter rye, spring wheat as shelter crop for meadow clover, first year clover, second year clover, spring barley, potato, oats. Certified seeds were used for sowing.

Treatment placing is randomized, each treatment has four replications on field area(basic plot $79.6 \mathrm{~m} 2$ ) and two replications in time.

Soil and plant chemical analyses were fulfilled in analytical laboratory of Perm Agricultural Research Institute according national standarts: humus content -GOST 26213-84(Tyurin method); pHKCl-GOST 26483-85(potentiometrically); hydrolytic acidity (HA)-GOST 2 OST 26207-91(Kappen method); total exchange bases(S) and exchange bases saturation (V) - GOST 27821-88 (KappenGilkovits method); content of mobile phosphorus and exchange potassium GOST 26207-91 (Kirsanov method).

Heavy metals soil content - defined in Perm agrochemical service center. Data processing included analysis of variance (least significant difference - LSD) and correlation coefficients (r) determination.

\section{RESULTS AND DISCUSSION}

Long-term application of fertilizers, within 40 years, had essential impact on change of soil agrochemical properties (table 2). So, arable land treatment without fertilizers led to considerable decrease of humus and potassium content, then, to some increase of soil acidity. Mineral fertilization systems, especially high fertilizers rates, caused base saturation decreasing and, vice versa, exchange and hydrolytic acidity raising. Humus content was relatively stable. FYM application provided humus content preservation or moderate increasing, up to $2.43 \%$ from highest rate $160 \mathrm{t} \mathrm{ha}^{-1}$.(c) Soil $\mathrm{pH}_{\mathrm{KCI}}$ reached 5.3 .

Table 2. The influence of fertilization systems on soil chemical properties.

(The end of fifth rotation, average for two replications in time).

\begin{tabular}{|c|c|c|c|c|c|c|c|}
\hline \multirow[b]{2}{*}{ Treatment } & \multirow{2}{*}{$\begin{array}{c}\text { Humus, } \\
\%\end{array}$} & \multirow[b]{2}{*}{$\mathrm{pH}_{\mathrm{KCI}}$} & S & На & \multirow[b]{2}{*}{$\mathrm{V}, \%$} & $\mathrm{P}_{2} \mathrm{O}_{5}$ & $\mathrm{~K}_{2} \mathrm{O}$ \\
\hline & & & \multicolumn{2}{|c|}{$\begin{array}{c}\mathrm{mmol} / 100 \mathrm{~g} \\
\text { of soil }\end{array}$} & & \multicolumn{2}{|c|}{$\begin{array}{c}\mathrm{mg} / 1000 \mathrm{~g} \text { of } \\
\text { soil }\end{array}$} \\
\hline a. Control & 2,12 & 4,9 & 19,2 & 3,07 & 86 & 173 & 163 \\
\hline b. FYM - $80 \mathrm{tha}^{-1}$ & 2,22 & 5,0 & 20,1 & 2,83 & 88 & 208 & 222 \\
\hline c. FYM - $160 \mathrm{t} \mathrm{ha}^{-1}$ & 2,43 & 5,3 & 20,0 & 2,54 & 89 & 210 & 262 \\
\hline d. NPK-eq 80 & 2,23 & 4,8 & 18,8 & 3,81 & 83 & 197 & 251 \\
\hline e. NPK-eq 160 & 2,31 & 4,4 & 17,2 & 4,43 & 80 & 256 & 316 \\
\hline f. FYM-40 + NPK-eq 40 & 2,35 & 4,9 & 18,5 & 3,26 & 85 & 201 & 268 \\
\hline g. FYM-80 + NPK-eq 80 & 2,46 & 5,1 & 19,6 & 2,95 & 87 & 248 & 339 \\
\hline h. FYM-160 + NPK-eq 160 & 2,70 & 5,1 & 17,9 & 3,70 & 83 & 333 & 433 \\
\hline $\operatorname{LSD}_{0.05} *$ & 0,23 & 0,3 & 1,3 & 0,71 & & 60 & 41 \\
\hline
\end{tabular}


The tendency of hydrolytic acidity decline was noted under organic and complex fertilization systems treatment. The most favourable soil conditions were worked in treatment c. NPK high doses (e) caused acidity raising and base saturation decreasing in spite of manure high rates using.

All fertilization systems have led to essential increase of exchange potassium content, especially treatments e,g,h (up to $433 \mathrm{mg} / 1000 \mathrm{~g}$ of soil). Situation with mobile phosphorus content was not so evident. Above-mentioned treatments promoted significant $\mathrm{P}_{2} \mathrm{O}_{5}$ increasing, in other treatments only the raising tendency was noted.

All studied systems of fertilizers have raised productivity of agricultural cultures compared with control. The most essential supplements of winter rye grain yield were obtained from treatments b,c,e - 0.46-0.54 t ha ${ }^{-1}$ (table 3). Application of $80 \mathrm{t} \mathrm{ha}^{-1} \mathrm{FYM}$ guaranteed winter rye yield equal to the one from higher fertilizers rates. Mineral and complex fertilization systems, en bloc conceded the organic system. The difference between these treatments has not exceeded LSD 05 value. The supplements of winter rye grain yield were due to raising individual ear productivity, correlation coefficients $(r)$ between total yield and grain quantity; grain mass from one ear were 0.6 and 0.64 , accordingly. Spring grain crops have also positively responded on all stu-died systems of fertilizers. Spring wheat grain yield raised from 2.30 to $3.85 \mathrm{t} \mathrm{ha}^{-1}$. The greatest supplements 1.17-1.55 $\mathrm{t} \mathrm{ha}^{-1}$ of grain yield were gained from treatments g,h,. The yield raising may be explained by increase of 1000 grains mass $(r=0,91)$.

All studied treatments have provided essential increase of clover hay yields compared with control. The maximum total (for two years) gain of clover hay $1.35 \mathrm{t} \mathrm{ha}^{-1}$ was received from $\mathbf{c}$, but the variances between treatments were insignificant, within LSD $_{05}$.

Treatments g,h showed some benefits for barley yields. Grain supplements were about 0.45-0.56 tha-1 without significant difference between them (table 3).

Table 3. Impact of fertilization on crop yields in fifth rotation.

\begin{tabular}{|c|c|c|c|c|c|c|}
\hline \multirow[b]{2}{*}{ Treatment } & \multicolumn{6}{|c|}{ Crop yields, $\mathrm{t} \mathrm{ha}^{-1}$} \\
\hline & $\begin{array}{l}\text { Winter rye } \\
\text { 2002-2003 }\end{array}$ & $\begin{array}{c}\text { Spring } \\
\text { wheat } \\
2003- \\
2004\end{array}$ & $\begin{array}{c}\text { Clover 2004- } \\
2006\end{array}$ & $\begin{array}{c}\text { Barley 2006- } \\
2007\end{array}$ & $\begin{array}{c}\text { Potato } \\
\text { 2007-2008. }\end{array}$ & $\begin{array}{r}\text { Oat } \\
2008 \\
2009\end{array}$ \\
\hline a. Control & 3,12 & 2,30 & 8,28 & 2,26 & 19,40 & 2,46 \\
\hline b. FYM - $80 \mathrm{t} \mathrm{ha}^{-1}$ & 3,60 & 2,77 & 9,03 & 2,42 & 24,11 & 3,00 \\
\hline c. FYM - $160 \mathrm{t} \mathrm{ha}^{-1}$ & 3,66 & 2,76 & 9,63 & 2,52 & 24,31 & 3,21 \\
\hline d. NPK-eq 80 & 3,36 & 2,89 & 9,41 & 2,42 & 24,96 & 3,25 \\
\hline e. NPK-eq 160 & 3,56 & 3,48 & 9,09 & 2,55 & 25,04 & 3,22 \\
\hline f. FYM-40 + NPK-eq 40 & 3,31 & 3,13 & 9,31 & 2,47 & 26,62 & 3,15 \\
\hline g. FYM-80 + NPK-eq 80 & 3,39 & 3,47 & 9,41 & 2,71 & 28,10 & 3,48 \\
\hline h. FYM-160 + NPK-eq 160 & 3,26 & 3,85 & 9,31 & 2,81 & 29,35 & 3,44 \\
\hline $\mathrm{LSD}_{05}$ & 0,24 & 0,25 & 0,69 & 0,22 & 2,61 & 0,31 \\
\hline
\end{tabular}


Grain yield rise was provided by stem thickness increase $(r=0.8)$ and 1000 grains mass $(r=0.79)$. Potato like all tuber cultures positively responds on FYM application, yield gains were about $4.9 \mathrm{t} \mathrm{ha}^{-1}$, but effect from mineral fertilizers was just the same. Combination of FYM and mineral fertilizers provided further raising of tubers yield, up to $29.35 \mathrm{t} \mathrm{ha}^{-1}$. This may be explained by high offtake of nutrients by potato tubers yields and heavy nutrients demand of this culture.

Significant supplements of oats grain were noted in all studied treatments - from 0.54 to $1.02 \mathrm{t} \mathrm{ha}^{-1}$. The efficiency of organic and mineral fertilization systems was roundly equal. Yield gains obtained in these treatments were within LSD 05 . Formation of the highest oat grain yield 3.44-3.48 $\mathrm{t} \mathrm{ha}^{-1}$ was provided by treatments g,h. Average crops productivity in fifth rotation varied from 2831 to $3859 \mathrm{FU}$ as influenced by fertilization systems. The maximum yields, but minimum crop returns were obtained in treatment h. The highest crop returns were obtained after mineral fertilizers application (d,e). Mineral fertilizers and FYM may be the sources of heavy metals soil contamination. So, heavy metals content evaluation was one of the aims of given experimental work. All studied fertilization systems have not led to soil pollution by mobile forms of heavy metals ( $\mathrm{Cu}, \mathrm{Zn}, \mathrm{Pb}, \mathrm{Cd})$. Their content in soil was far from maximum permissible concentration (table 4). Fertilizers application caused small raising of Zn content - from 1.20 to $2.38 \mathrm{mg} \mathrm{kg}^{-1}$. Some decreasing of copper content was noted: from $0.33 \mathrm{mg}$ (control) to $0.20-0.25 \mathrm{mg} \mathrm{kg}^{-1}$, without express tendency according the treatment. Probably, it was caused by $\mathrm{Cu}$ offtake with greater yields. Variations of $\mathrm{Pb}$ and $\mathrm{Cd}$ concentration were insignificant.

Table 4. Impact of fertilization on heavy metal status in soil at end of fifth rotation (2009) and in grain of winter rye (2010 - sixth rotation)

\begin{tabular}{|c|c|c|c|c|c|c|c|c|c|c|c|c|}
\hline \multirow{3}{*}{ Treatment } & \multicolumn{4}{|c|}{ Soil status } & \multicolumn{8}{|c|}{ Grain of winter rye } \\
\hline & $\mathrm{Cu}$ & $\mathrm{Zn}$ & $\mathrm{Pb}$ & $\mathrm{Cd}$ & $\mathrm{Cu}$ & $\mathrm{Zn}$ & $\mathrm{Pb}$ & $\mathrm{Cd}$ & $\mathrm{Cu}$ & $\mathrm{Zn}$ & $\mathrm{Pb}$ & $\mathrm{Cd}$ \\
\hline & \multicolumn{4}{|c|}{ Mobile form in soil ( $\mathrm{mg} \mathrm{kg}^{-1}$ ) } & \multicolumn{4}{|c|}{ Concentration (mg kg${ }^{-1}$ ) } & \multicolumn{4}{|c|}{$\begin{array}{c}\text { Biological accumulation } \\
\text { coefficients }\end{array}$} \\
\hline$a$ & 0.33 & 1.20 & 0.32 & 0.05 & 3.73 & 29.6 & 0.29 & 0.04 & 11.3 & 24.7 & 0.9 & 0.8 \\
\hline$b$ & 0.23 & 1.29 & 0.24 & 0.04 & 3.93 & 26.9 & 0.38 & 0.04 & 17.1 & 20.9 & 1.6 & 1.0 \\
\hline c & 0.29 & 1.35 & 0.43 & 0.03 & 4.08 & 25.8 & 0.36 & 0.05 & 14.1 & 19.1 & 0.8 & 1.7 \\
\hline$d$ & 0.20 & 0.95 & 0.35 & 0.02 & 3.93 & 28.3 & 0.35 & 0.05 & 19.7 & 29.8 & 1.0 & 2.5 \\
\hline$e$ & 0.22 & 1.43 & 0.28 & 0.04 & 4.50 & 29.7 & 0.30 & 0.04 & 20.5 & 20.8 & 1.1 & 1.0 \\
\hline$f$ & 0.24 & 2.25 & 0.34 & 0.05 & 3.55 & 25.0 & 0.35 & 0.03 & 14.8 & 11.1 & 1.0 & 0.6 \\
\hline$g$ & 0.24 & 2.25 & 0.34 & 0.05 & 3.48 & 25.3 & 0.38 & 0.03 & 14.5 & 11.2 & 1.1 & 0.6 \\
\hline$h$ & 0.25 & 2.38 & 0.25 & 0.05 & 3.55 & 25.3 & 0.38 & 0.04 & 14.2 & 10.6 & 1.5 & 0.8 \\
\hline $\operatorname{LSD}_{0.05}$ & 0.04 & 0.80 & $\mathrm{~F} \phi<\mathrm{FT}$ & 0.01 & 0.76 & 3.42 & 0.05 & $\mathrm{~F} \phi<\mathrm{FT}_{\mathrm{T}}$ & & & & \\
\hline MPC* & 3.0 & 23.0 & 6.0 & - & 10.00 & 50.0 & 0.50 & 0.1 & & & & \\
\hline \multicolumn{5}{|l|}{ MPL $^{* *}$} & 30.00 & 50.0 & 5.00 & 0.3 & & & & \\
\hline
\end{tabular}

Notes: *MPC - maximum permissible concentration; ** MPL - maximum permissible level 
Heavy metals concentration is very important parameter of agricultural product quality. Copper and zinc are important elements for plants metabolism, without them many enzymatic biochemical reactions in plants are impossible. The copper concentration in studied treatments was varying from 3.8 to 4.50 $\mathrm{mg} / \mathrm{kg}$ (table 4). The essential increase - up to $4.50 \mathrm{mg} / \mathrm{kg}$, was observed only in treatment e, but it was essentially lower MPL $-30 \mathrm{mg} / \mathrm{kg}$. Joint application of manure with mineral fertilizers essentially decreased zinc content in winter rye grain. Some authors (Gomonova, 1994; Chernych et al., 1995; Nosovskaya et al., 2000) noted that some heavy metals metals, for example, zinc and copper, forming organic-mineral complexes with soil organic substance, became less available to plants.

Long-term application of manure single and together with mineral fertilizers caused $\mathrm{Pb}$ accumulation in grain, but, its concentration was below MPC and MPL. All studied fertilization systems have no effect for Cd accumulation in winter rye grain. The gained harvest may be used, both for food, and for the fodder purposes. Hence, in general, joint application of FYM and mineral fertilizers promotes decrease of heavy metals accumulation in agricultural product and its quality improvement..

\section{CONCLUSIONS}

Joint application of manure and mineral fertilizers in rates nor less than FYM $40 \mathrm{t} \mathrm{ha}^{-1}+$ NPK in equivalent rates promoted humus accumulation in soil, guaranteed mobile phosphorus and potassuim content raise, soil status quo in regard to acidity and exchange base saturation.

All studied fertilization systems increased crops yields in field eightcourse rotation, but the highest supplements were obtained by application of complex fertilization systems with FYM rates $80 \mathrm{t} \mathrm{ha}^{-1}$ and more. Average crops productivity in fifth rotation varied from 2831 to $3859 \mathrm{FU}$ as influenced by fertilization systems. The maximum yields, but minimum crop returns were obtained from combination of manure total rate $160 \mathrm{t} \mathrm{ha}^{-1}$ within rotation and equivalent mineral fertilizers application. The highest crop returns were gained after mineral fertilizers application.

Long-term application of organic and mineral fertilizers has not caused soil and agricultural product pollution by heavy metals above MPC and MPL. Complex fertilization systems possess some advantage in this position compared with mineral fertilizers and promote the improvement of agricultural product quality.

\section{REFERENCES}

Alexeev, Y..V., 1987. Heavy metals in soils and plants. Agropromizdat. Leningrad.

Chernych N.A. LadoninV.F., 1995. Problems of heavy metals rationing in soil. Chemistry in ag-riculture 5, 10-13.

Gomonova, N.F., 1994. Influence of agrochemical preparations long application on sodpodsolic soils on transformation of heavy metals in system soil-plant. In: Heavy 
metals and radio-active nuclides in agroecological systems. Proceeding of scientific conference:. Mos-cow, 180-186.

Ladonin, V.F., 1995. I nfluence of complex chemicals application on heavy metals accumulation in soil and plants. Chemistry in agriculture 4, 32-34.

Mineev, V.G., Gomonova N.F., Zenova G. M, Skvortsova I.N., 1999. Properties change of sod-podsolic soil and its bacterium coenosis from intensive cultivation. Soil science 4, 455-460

Mineev V.G., 2008. Agrochemistry and environmental problems of modern agriculture. In: Pro-ceeding of Russian meeting of the Geographical experiments network with fertilizers. Moscow, 5-8.

Naydin P.G., 1967. Geographical distribution of mineral fertilizers efficiency in the USSR. Agrochemistry, 1, 24-40.

Nebolsin A.N., Nebolsina Z.P., 2005. Theoretical bases of soils liming. Agr. Inst. St.Petersburg.

Nosovskaya I.I., Soloviev G.A, Egorov V. S, 2000. The influence of long-term systematic application of mineral fertilizers and manure on copper and zinc accumulation in soil. Agrochemistry, 9, 50-56.

Obuhov A.I., Popova A.A., 1992, Balance of heavy metals in sod-podsolic soils coenoses and monitoring problems. Annals of Moscow State University. Part. 17, Soil science, 3, 31-39.

Petuchov M.P., Prokoshev V.N. 1964. Application of fertilizers in the Ural Region. Perm. Ramad F., 1981. Bases of applied ecology. Gidrometeoizdat. Leningrad.

Voytovich N.V., Kirdin V. F., Polev N.A., 1990. How to rescue fertility of soils of NonBlack Earth Region. Husbandry, 5, 20-21.

Yakovleva L.V., 2009. Ecological aspects of sod-podsolic soils liming in the Northwest of Rus-sia. DSc Agr. thesis abstract. St.-Petersburg - Pushkin. 